\title{
鉄鋼材料中に生成する硫化物の 状態図とミクロ組織制御
}

及川勝成 ${ }^{*}$ 光井 啓** 石田清化**

\section{1.はじめに}

鉄鋼材料中に生成する $\mathrm{FeS}$ や $\mathrm{MnS}$ などの硫化物は，機械 的性質や耐食性などの種々の特性に大きな影響を及ぼす事が 知られている、特に有名なのが $\mathrm{FeS}$ にっって生じる赤熱脆 化で，除去されるべき介在物の代表である，一方，電磁鋼板 やイオウ快削鋼などの一部の鋼種では, MnS の存在が材質 制御のために不可欠で積極的に添加されている。このため $\mathrm{FeS}$ や MnS に関するミクロ組織形態と状態図に関する研究 は古くから行われている。

近年，オキサイド・メタラジー研究の提案(1)をきっかけ に, 鉄鋼材料中の非金属介在物を有效な組織因子として活用 しようとする研究が活発となってきている，硫化物も材質制 御に積極的に利用する試みが行われており, 最近では高ク口 么耐熱鋼中の微細な硫化物が, 耐水蒸気酸化特性の改善に有 効なことが明らかにされている(2).鉄鋼材料中に沶ける硫化 物形成傾向は, $\mathrm{Zr}>\mathrm{Ti}>\mathrm{Mn}>\mathrm{Nb}>\mathrm{V}>\mathrm{Cr}>\mathrm{Al}>\mathrm{Mo}>\mathrm{W}>$ $(\mathrm{Fe})>\mathrm{Ni}>\mathrm{Co}>\mathrm{Si}$ の順(3)で多くの金属元素が硫化物を形成 する，それら硫化物を組織制御へ利用するには，多元系状態 図に関する情報が必要不可欠である。しかし，鉄鋼材料中に 打ける硫化物の相平衡や熱力学データ瓦関する研究は, FeS 上 $\mathrm{MnS}$ を対象とするものが中心であり，他の硫化物に関し ては極めて少ない。

我々は，多元系状態図計算に有用なCALPHAD 法を用い て, 硫化物を含む多元系熱力学データベースの開発を行って 打り，MnS, CrS, TiSなどの硫化物に関する多元系状態 図(4)-(6)については, 定量的に計算することが可能となって
いる. また，データベースを活用しながら硫化物の形態・分 散状態の制御(7)-(12)，更に硫化物老分散させた新材料の開発 も行っている(13)(14)。本稿では, 種々の $\mathrm{Fe}-\mathrm{MS}$ 系状態図と 硫化物形態の関連を概説するとともに，多元系計算状態図の 新材料開発への応用例を紹介する。

\section{2. 金属 $(\mathbf{M})$-金属硫化物 $(\mathbf{M S})$ 系状態図の分類}

鉄鋼材料中に生成する硫化物のミクロ組織形態は, 状態図 々密接に関連する。鉄銅材料中の炭化物や窒化物に関する多 元系状態困に比べ，硫化物に関する多元系状態図の研究は極 めて少ない，しかし，多元系状態図では 2 元系状態図が基 本となるので, 金属 $(\mathrm{M})$ - 金属硫化物 $(\mathrm{MS})$ 系状態図と金属 (M) - 金属炭化物 $(\mathrm{MC})$ 系状態図の比較からまず述べる. 図 1 は，M-MS 系および M-MC 系状態図の型式を周期表に準 じてまとめたものである. 液相と固相の関与する不変系反応 々融点の関係办ら, 次の 5 つの型式の状態図に分類でき る(15). $\mathrm{M}_{1}$ 型：2 液相分離と偏晶反応 $\left(\mathrm{L}_{1} \rightarrow\right.$ 固相 $\left.+\mathrm{L}_{2}\right)$ が存在 し，金属の融点が化合物の融点より高い. $\mathrm{M}_{2}$ 型 $: 2$ 液相分 離と偏晶反応 $\left(\mathrm{L}_{2} \rightarrow\right.$ 固相 $\left.+\mathrm{L}_{1}\right)$ が存在し, 金属の融点が化合 物の融点より低い， $\mathrm{E}_{1}$ 型：液相が全率可溶で共晶反応が存 在し，金属の融点が化合物の融点より高い， $\mathrm{E}_{2}$ 型：液相が 全率可溶で共晶反応が存在し，金属の融点が化合物の融点よ り低い。 $\mathrm{P}_{1}$ 型：液相が全率可溶で包晶反応が存在し, 金属 の融点が化合物の融点より低い. 眼 1(a)の M-MS 系の状態 図の分類は，西沢による分類(15)を参考にしながら，最新の データ(16)を付け加えたものである. 図1(b)に示した M$\mathrm{MC}$ 系と比較すると，炭化物は融点が高く $\mathrm{E}_{2}$ 型西るいは $\mathrm{P}_{1}$

* 産業技術総合研究所基礎素材研究部門主任研究員 ( $983-5211$ 仙台市宮城野区苦竹4-2-1)

*** 東北大学大学院生; 大学院工学研究科材料物性学専攻

*** 東北大学教授; 大学院工学研究科材料物性学専攻

Phase Diagrams and Microstructure Control of Sulfide in Steel; Katsunari Oikawa*, Hajime Mitsui**, Kiyohito Ishida*** (*National Institute of Advanced Industrial Science and Technology, Institute of Structural and Engineering Materials, Sendai. **,*** Department of Materials Science, Graduate School of Engineering, Tohoku University, Sendai)

Keywords: phase diagram, sulfide, steel, metastable reaction, monotectic, eutectic, machinability 2004年 2 月19日受理 
型になる状態図が多いが，M-MS 系では，金属と硫化物が 2 液相分離し $\mathrm{M}_{1}$ あるいは $\mathrm{M}_{2}$ 型となる系が多いのが特徴で ある.また， $\mathrm{E}_{1}, \mathrm{E}_{2}$ 型に属する系でも $\mathrm{Fe}-\mathrm{FeS}$ 系のように 2 液相分離が準安定系で存在する系も多い。これは, 硫化物が イオン結合の傾向が強いのに対して, 炭化物は共有結合の傾 向が強いという結合様式と関連していると考えられる ${ }^{(15)}$.

このような 2 液相分離が生じやすい傾向は, Fe-M-S 3 元 系状態図にも引き継がれる. 図 2 は, Fe 中にみられる典型 的な硫化物の $\mathrm{Fe}-\mathrm{MS}$ 擬 2 元系状態図と液相が関与する共役
線の模式図を示している. 図 $2(\mathrm{a})$ は $\mathrm{Fe}-\mathrm{Cr}-\mathrm{S}$ 系の模式図を 示している ${ }^{(8)} \cdot \mathrm{Cr}-\mathrm{CrS}$ 系に 2 液相分離があり，それが 3 元 系においても大きく広がる. $\mathrm{Fe}-\mathrm{CrS}$ 擬 2 元系状態図は $\mathrm{M}_{1}$ 型となる. $\mathrm{Fe}$ より融点が低い硫化物を生成する $\mathrm{Fe}-\mathrm{Al}_{2} \mathrm{~S}_{3}$ 系 も同様な状態図となる ${ }^{(17)}$. 図 $2(\mathrm{~b})$ は $\mathrm{Fe}-\mathrm{Mn}-\mathrm{S}$ 系の模式図 を示している(5). Mn-MnS 2 元系に存在する 2 液相分離が 3 元系においても大きく広がる. また, $\mathrm{MnS}$ の融点が $\mathrm{Fe}$ よ りも高く, $\mathrm{Fe}-\mathrm{MnS}$ 擬 2 元系状態図は $\mathrm{M}_{2}$ 型となる。図 2 (c) は Fe-Ti-S 系の模式図を示している(18). この系の基本 (a) 金属 $(\mathrm{M})$ - 硫化物 $(\mathrm{MS})$ 系

\begin{tabular}{|c|c|c|c|c|c|c|c|c|c|c|c|}
\hline $\mathbb{I}_{\mathrm{a}}$ & $\mathrm{I}_{\mathrm{a}}$ & $V_{a}$ & $\mathrm{VI}_{\mathrm{a}}$ & $\mathrm{VII}_{a}$ & & $\mathrm{VIII}_{2}$ & & $I_{1}$ & & $\mathrm{M}_{2}$ & \\
\hline $\mathrm{ScS}$ & $\mathrm{TiS}$ & $\mathrm{VS}$ & $\mathrm{CrS}$ & $\mathrm{MnS}$ & $\mathrm{FeS}$ & & 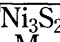 & & & $\mathrm{GaS}$ & $\mathrm{GeS}$ \\
\hline & & & $M_{1}$ & $\mathrm{M}_{2}$ & $E_{1}$ & $E_{1}$ & $\mathrm{M}_{2}$ & $\mathrm{M}_{2}$ & $\mathrm{M}_{2}$ & $\mathrm{M}_{2}$ & M \\
\hline$\underset{?}{\text { YS }}$ & $\mathrm{ZrS}$ & NbS & $\mathrm{Mo}_{2} \mathrm{~S}$ & $\mathrm{TcS}_{2}$ & $\mid \operatorname{RuS}_{2}$ & $\mathrm{RhS}$ & $\mathrm{PdS}$ & $\mathrm{Ag}_{2} \mathrm{~S}$ & $\mathrm{CdS}$ & InS & SnS \\
\hline $\mathrm{RE}-\mathrm{C}$ & HfS & $\mathrm{Ta}_{2} \mathrm{~S}$ & $\begin{array}{l}L_{1} \\
\mathrm{WS}_{2}\end{array}$ & $\frac{\vdots}{\mathrm{ReS}_{2}}$ & $\mathrm{OsS}_{2}$ & \begin{tabular}{|l|} 
\\
$\mathrm{IrS}_{2}$
\end{tabular} & $\frac{L_{1}}{\mathrm{PtS}}$ & $\frac{v_{1}}{A u}$ & $\frac{\mathbf{L}_{2}}{\mathrm{HgS}}$ & $\frac{\mathrm{v}_{2} \mathrm{~T}^{2}}{\mathrm{~T}}$ & $\frac{\mathrm{v}_{2}}{\mathrm{PbS}}$ \\
\hline $\mathrm{E}_{2}$ & $?$ & $?$ & $E_{1}$ & $\mathrm{E}_{1}$ & & $?$ & $\mathrm{E}_{1}$ & & $\mathrm{M}_{2}$ & $\mathrm{M}_{2}$ & $\mathrm{~N}$ \\
\hline
\end{tabular}

(b) 金属 $(\mathrm{M})$ - 炭化物 $(\mathrm{MC})$ or 炭素 $(\mathrm{G})$ 系

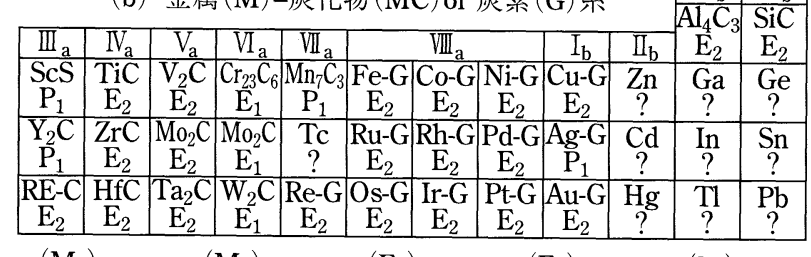

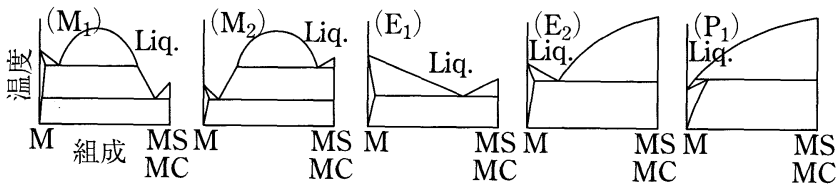

図 1 (a) 金属 $(\mathrm{M})$ - 硫化物 $(\mathrm{MS})$ および (b) 金属 $(\mathrm{M})$ 炭化物 $(\mathrm{MC})$ の状態図の分類.

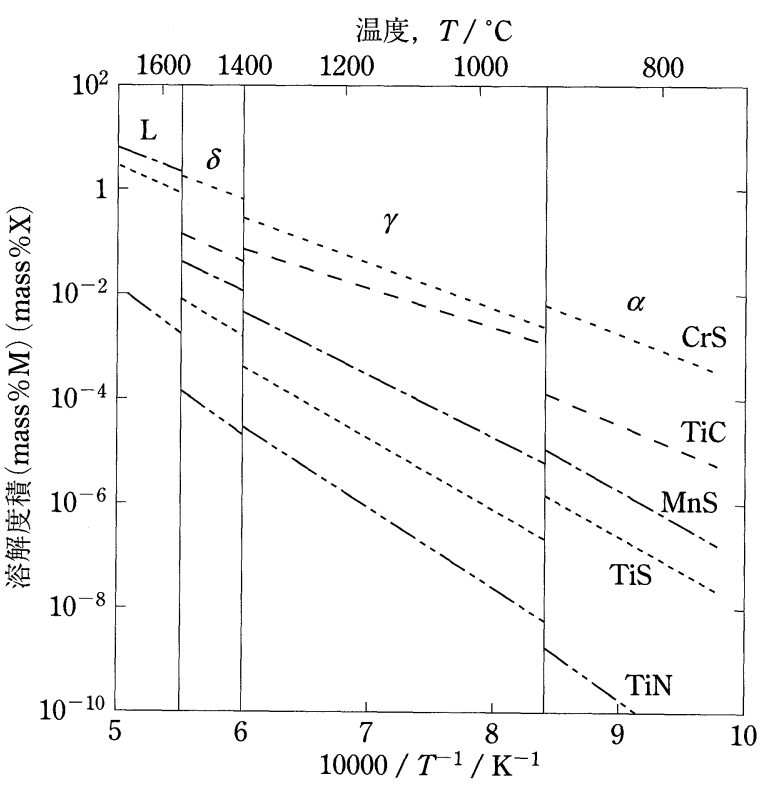

図 $3 \mathrm{Fe}$ 中における硫化物の溶解度積.
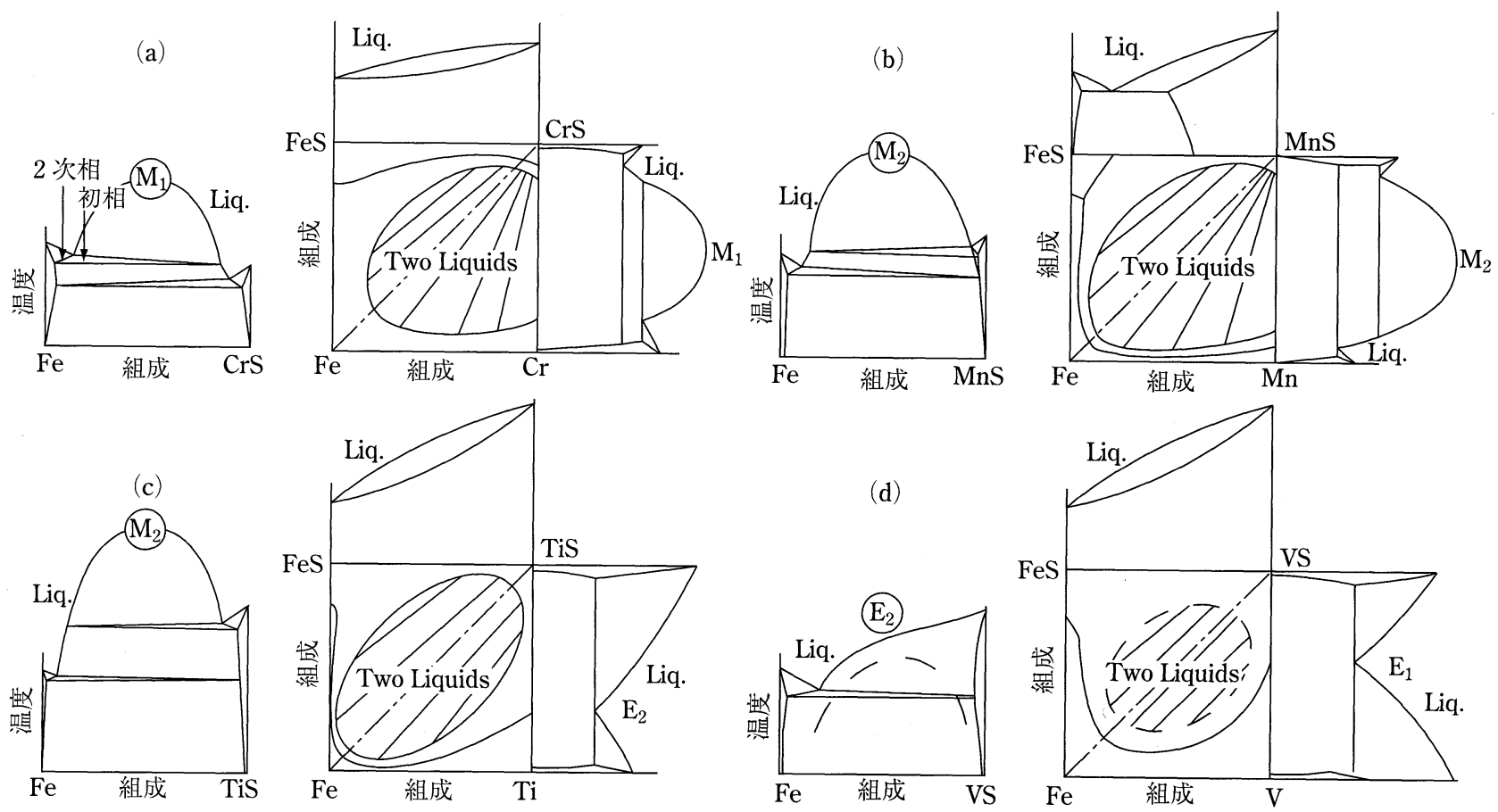

図 $2 \mathrm{Fe}-\mathrm{M}-\mathrm{S}$ 系の液相線の模式図と Fe-MS 擬 2 元系の形態分類. 
となる Ti-TiS 2 元系には 2 液相分離が存在しないが, Fe の液相と TiS の液相の熱力学的な安定性に大きな差がある ために，Fe と TiSへの 2 液相分離が島状に現れる。また， TiS の融点が $\mathrm{Fe}$ よりも高く $\mathrm{Fe}-\mathrm{TiS}$ 擬 2 元系状態図は $\mathrm{M}_{2}$ 型となる. 図 3 (d) は Fe-V-S 系の模式図を示している(17). この系では 2 液相分離は安定系状態図では現れず，Fe-VS 擬 2 元系状態図は $\mathrm{E}_{2}$ 型となる. しかし，このような系にお いても, 破線で示されるような準安定系の 2 液相分離が隠 れていることが多い，以上の上うに, $\mathrm{Fe}-\mathrm{MS}$ 擬 2 元系状態 図でも偏晶反応が存在する $\mathrm{M}_{1}$ あるいは $\mathrm{M}_{2}$ 型となる系が多 い, 一方, 図面は省略するが, $\mathrm{Fe}-\mathrm{MC}$ 系の多くは, 炭化物 の融点が $\mathrm{Fe}$ よりも高く $\mathrm{E}_{2}$ 型となる傾向が強い.

\section{Fe 中の硫化物の溶解度積}

$\mathrm{Fe}$ 中の溶解度積が明らかになっている硫化物は極めて少 ない. 図 3 に熱力学計算から求めた $\mathrm{CrS}^{(4)}, \mathrm{MnS}^{(5)}$ 抢よび $\mathrm{TiS}^{(18)}$ の溶解度積の值を $\mathrm{TiN}^{(19)}$, $\mathrm{TiC}^{(20)}$ の値と合わせて示 した，図面中では省略しているが，多くの炭化物，窒化物の 溶解度積は，TiNや $\mathrm{TiC}$ のようにオーステナイト相のほう がフェライト相よりも大きくなる。一方，硫化物はオーステ ナイト相のほうがフェライト相よりも小さくなるという逆の 傾向を示すのが特徴である。

\section{4. 鉄鋼材料中に生成する硫化物の形態分類}

ここでは $\mathrm{Fe}$ の凝固中に生成する硫化物の典型的な形態に ついて述べる。凝固時に生成する硫化物としては, 図 2(a) の $\mathrm{Fe}-\mathrm{MS}$ 擬 2 元系状態㘠に示したように，偏晶点(または 共晶点) 上り硫化物側の組成では初相として硫化物が生成す る。一方, Fe 側の組成では, 初相として Feの固相が析出 し，その後，偏晶(または共晶)反応により 2 次相として硫 化物が生成する。図 4 は, 初相として生成する硫化物の SEM 像を示している. 図 4(a)に示した球状硫化物は，その 形態から生成した時は液相であったと考无られる。つまり， 2 液相分離により生成すると考元られ, 通常は $\mathrm{M}_{1}$ 型の状態 図の場合に観察されることが多い. 図 4(b)，(c)に示したデ ンドライト状抢よび角状硫化物は, その形態から固相の硫化 物が晶出したのは明らかであり, 液相の過飽和度の違いで形 態が変化する。この硫化物は $\mathrm{M}_{2}$ 型の状態図の場合に観察さ れる. 図 5 は, 2 次相として生成する硫化物の SEM 像を示 している. 図 5(a)に示したセルウォール状硫化物は, 最終 凝固部にネットワーク状に析出している， $\mathrm{Fe}-\mathrm{FeS}$ 系などの ような $\mathrm{E}_{1}$ 型の状態図の場合に観察される。図 5 (b)に示した 偏晶硫化物は, Sims と Dahleの古典的分類では Type I に 相当する(21).この硫化物は生成時は液相だったと考元られ， $\mathrm{Fe}$-rich の液相 $\left(\mathrm{L}_{1}\right)$ 加ら固相の $\mathrm{Fe}$ と液相の硫化物 $\left(\mathrm{L}_{2}\right) へ の$ 偏晶反応 $\left(\mathrm{L}_{1} \rightarrow \mathrm{Fe}(\mathrm{s})+\mathrm{L}_{2}\right)$ により生成する。つまり, $\mathrm{M}_{1}$ 型 の状態図の場合に観察される。図 $5(\mathrm{c})$ ，(d) は， $\mathrm{M}_{2}$ および $\mathrm{E}_{2}$ 型の状態図で観察される形態で, 液相 $\left(\mathrm{L}_{1}\right)$ 汃ら固相の $\mathrm{Fe}$
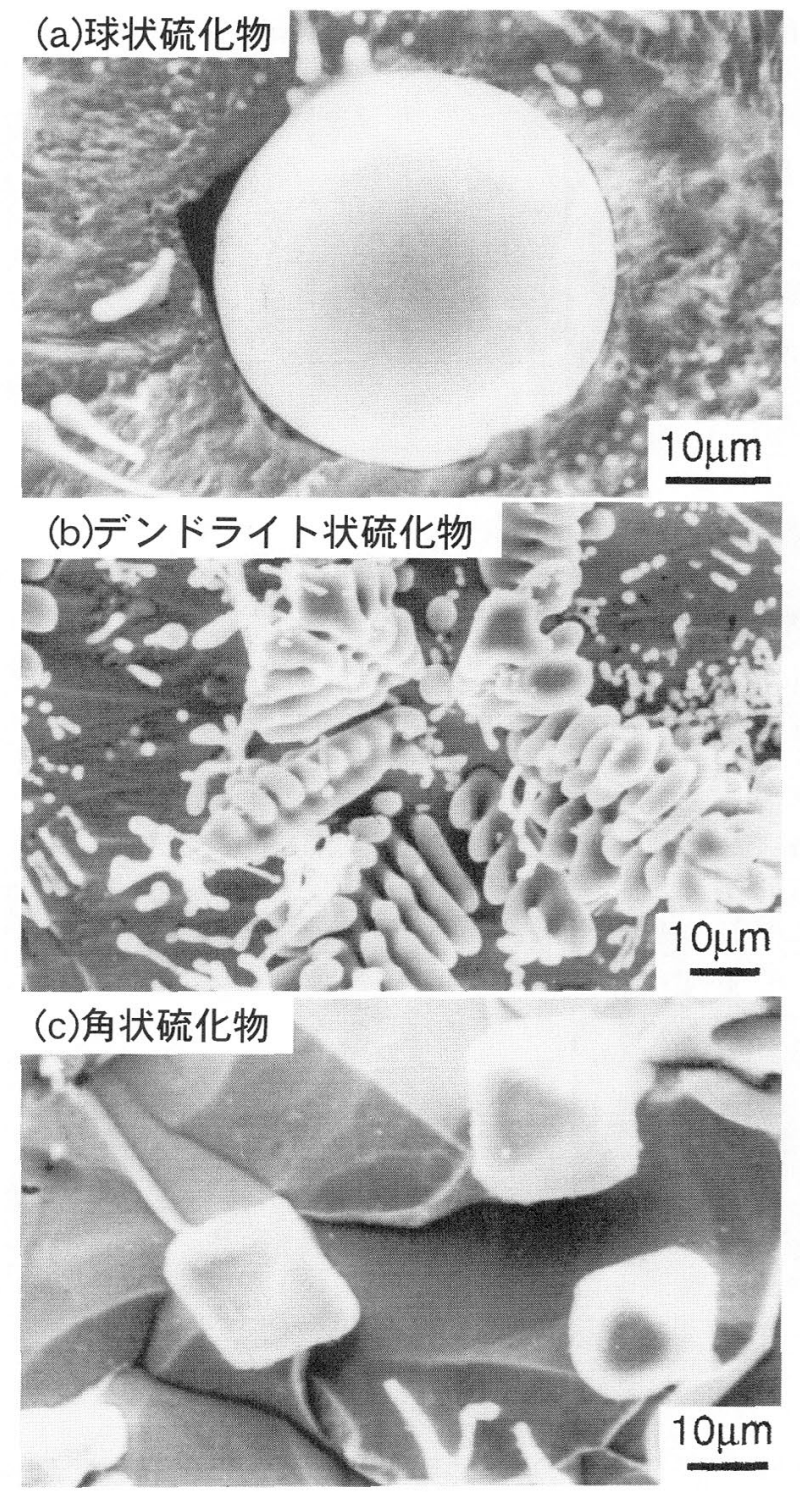

図 4 初相として生成する硫化物の典型的な SEM 像.

と固相の硫化物への共晶反応 $\left(\mathrm{L}_{1} \rightarrow \mathrm{Fe}(\mathrm{s})+\mathrm{MS}(\mathrm{s})\right)$ により生 成する. 図 5 (c) の棒状共晶硫化物は Sims 上 Dahle の分類 の Type II に相当し(21)，Fe相と硫化物相が協調的に成長す る典型的な共晶組織である. 圀 5 (d) の変則共晶硫化物は Fredriksson と Hillert が fish-born 型と分類したものに相当 し(22), 共晶点が著しく $\mathrm{Fe}$ 側に偏った場合に観察され，い わゆる分離共晶により生成したと考光られる。

完全に凝固した後, 初相 $\mathrm{Fe}$ 相内のイオウの固溶限が冷却 にともない小さくなると, Fe 相内に硫化物が析出してく る. 図 6 は典型的な析出硫化物のミクロ組織を例示してい る(12). 図6(a)に示した微細球状硫化物は, 図 4(a), 5(a)に 示した球状, 偏晶硫化物と比較すると, 大きさが $500 \mathrm{~nm}$ 以 下と非常に小さく, 且つ均一に分散している。この形態は低 融点の硫化物が生成する時に観察され，析出した時点では液 相だったと考えられる。一方, 図 6(b)に示した針状硫化物 は, 高融点の固相硫化物が析出する時に観察され, その際マ 
(a)セルウォール状硫化物 (b)偏晶硫化物

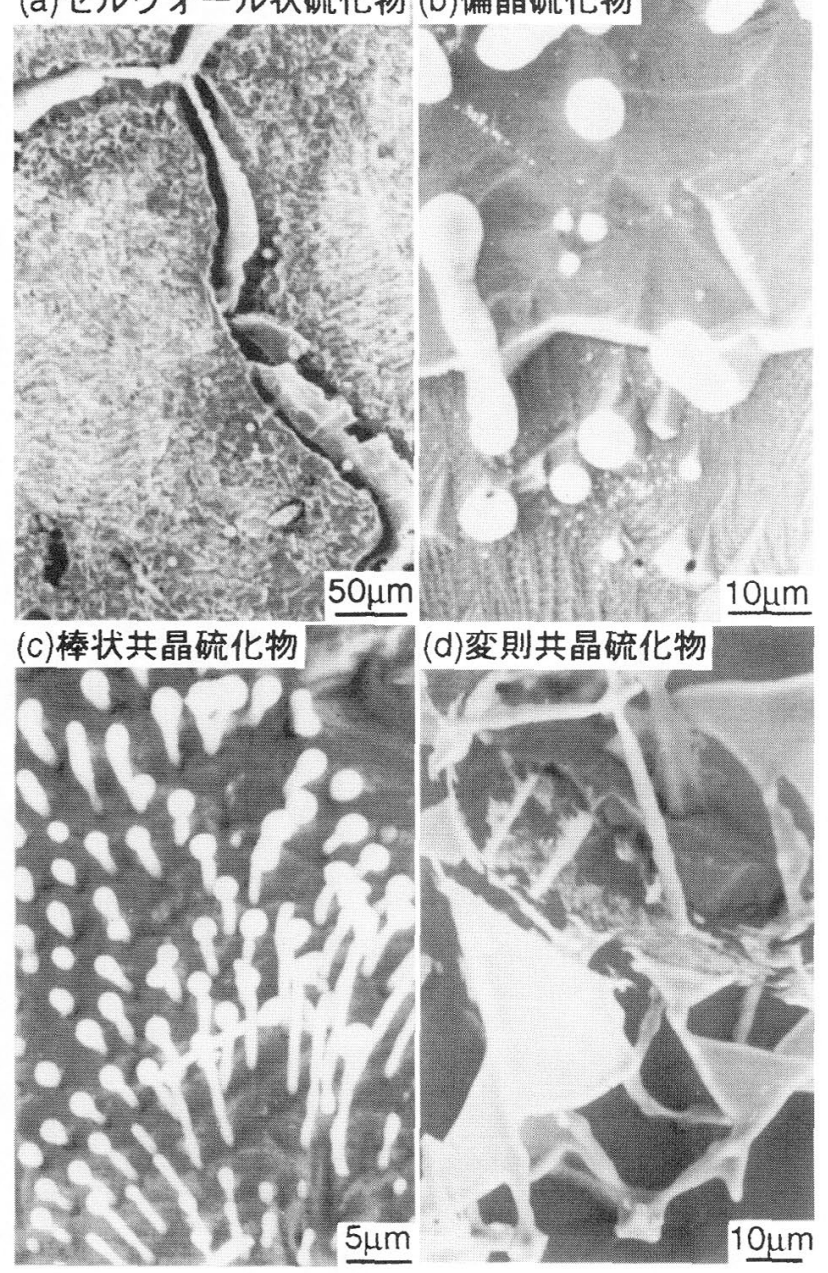

戍 52 次相として生成する硫化物の典型的な SEM 像.

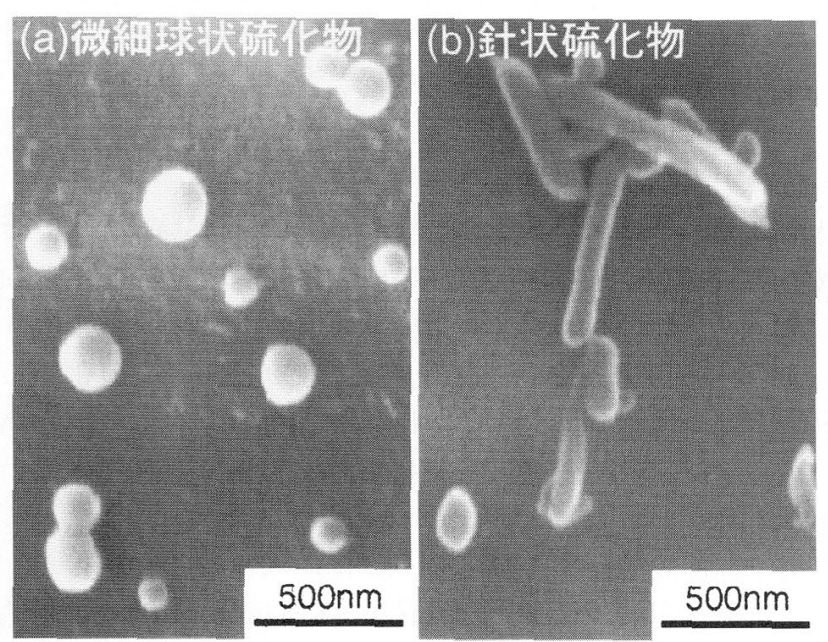

図 6 固相 $\mathrm{Fe}$ 中に析出する硫化物の典型的な SEM 像.

トリックスと特定の方位関係を保ちながら生成したと推察さ れる。 (a) 初相として生成する $\mathrm{MnS}$ の形態

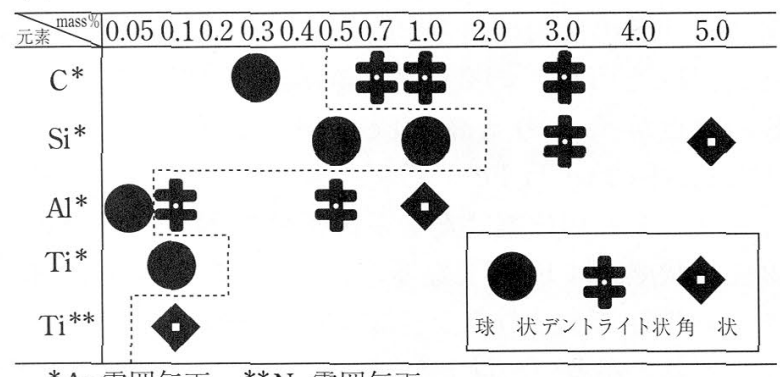

${ }^{*} \mathrm{Ar}$ 需囲気下 ${ }^{* *} \mathrm{~N}_{2}$ 需囲気下

(b) 2 次相として生成する $\mathrm{MnS}$ の形態

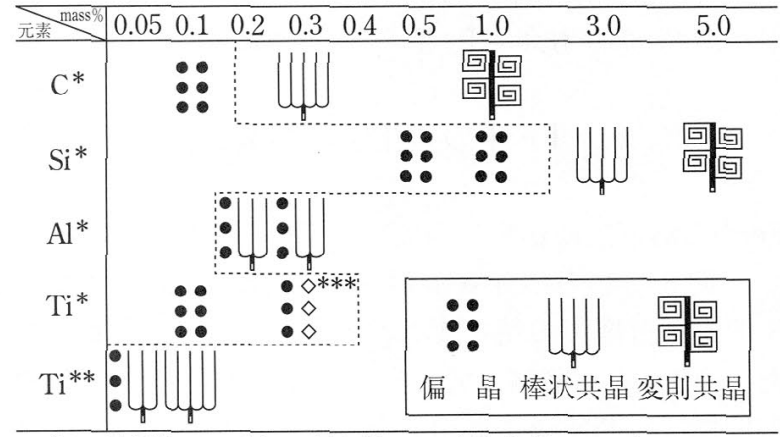

${ }^{*} \mathrm{Ar}$ 雲国気下 ${ }^{* *} \mathrm{~N}_{2}$ 雲囲気下 ${ }^{* * * *}$ 共晶 $\mathrm{TiS}+$ 偏唱 $\mathrm{MnS}$

図 $7 \mathrm{Fe}$ 中に (a) 初相抢よび(b) 2 次相として生成する $\mathrm{MnS}$ の添加元素による形態变化.

\section{5. 鉄鋼材料中に生成する $\mathrm{MnS}$ の形態制御}

鉄鋼材料中に生成する最も一般的な硫化物は MnS であ る. その形態は, 凝固条件や添加元素の種類により变化する ことが知られている. 図 7 は初相拉よび 2 次相として生成 する MnS 形態と添加元素の関連をあとめたものである(7)(8). Fe-Mn-S 3 元系では, 矢れぞれ球状, 偏晶硫化物が生成す る。注目すべき点は, Ti 添加の場合である. Ar ガス雾团気 下で溶解した場合, 球状山るいは偏晶硫化物のままである が，窒素ガス雾团気下では角状扔よび棒状共晶硫化物へと変 化する。これは溶鉄中に $\mathrm{MnS}$ に先立って生成する酸化物や 窒化物が MnS 形態に大きな影響を及ぼすことを示唆してい る.

$\mathrm{Fe}-\mathrm{MnS}$ 擬 2 元系状態図は, 図 2 (a) の上うに $\mathrm{M}_{2}$ 型に属 するのにも拘わらず，Fe-Mn-S 3 元系合金では，球状，偏 晶硫化物が生成する. $\mathrm{Fe}-\mathrm{MnS}$ 擬 2 元系状態図中で, 固体 $\mathrm{MnS}$ が生成しないという条件で準安定状態図を考えると, 図 8(a)に破線で模式的に示されるような状態図を描くこと ができる( ${ }^{(8)}$.この状態図に従えば球状および偏晶硫化物が生 成することが期待できる。図 8(b) は，この仮定に従い熱力 学的手法で計算した Fe-rich 側の安定系, 準安定系状態図を 示している. 固相 $\mathrm{MnS}$ が生成する安定系と液相 $\mathrm{MnS}$ が生 成する準安定系の温度差は小さく, 僅かな過冷により準安定 系の反応が進行する可能性を示唆している.

安定系および隼安定系反応のいずれが優先的に進行するか 

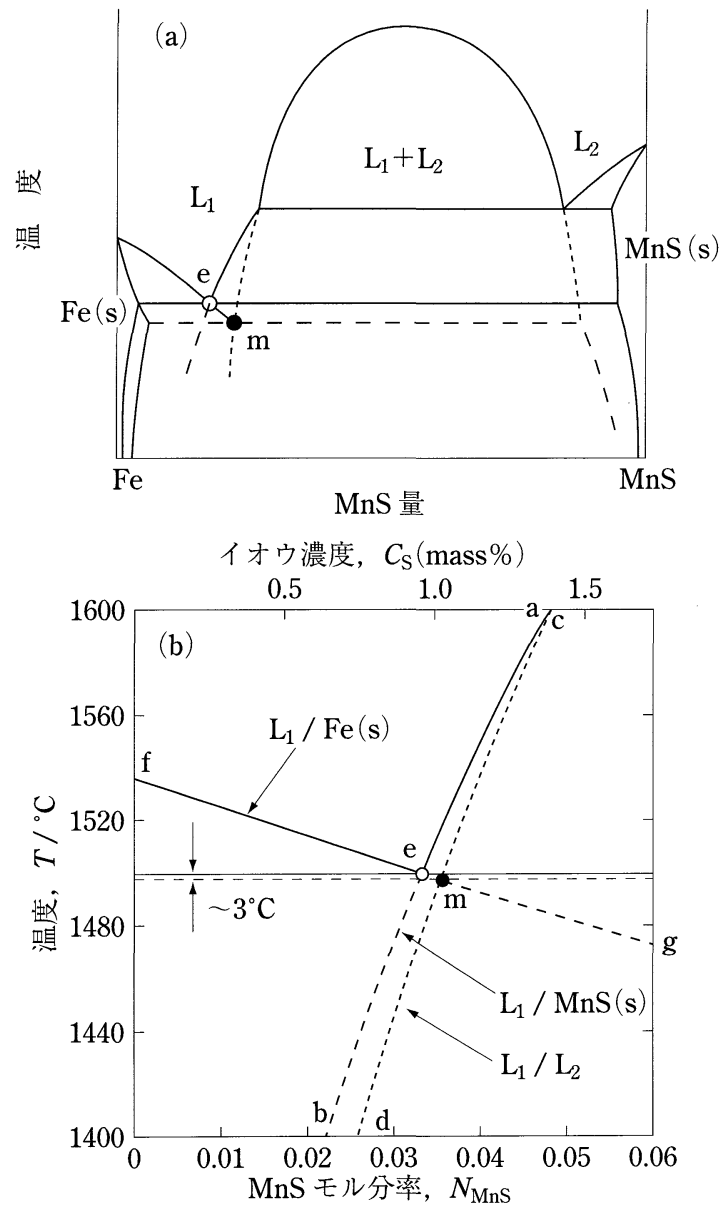

図 $8 \mathrm{Fe}-\mathrm{MnS}$ 擬 2 元系状態図.（a）全体の模式図.

(b) Fe-rich 側の計算状態図. 実線は安定系, 破 線は準安定系状態図.

を判断する因子は, Fe-rich の液相 $\mathrm{L}_{1}$ から液相 $\mathrm{MnS}\left(\mathrm{L}_{2}\right)$ お よび固相 $\mathrm{MnS}(\mathrm{s})$ の核生成の容易さである，核生成頻度は一 般に $\exp \left(-\Delta g_{\max } / k T\right)$ に比例する。ここで $\Delta g_{\text {max }}$ は, 過飽 和液相 $\mathrm{L}_{1}$ から $\mathrm{MnS}$ が核生成する際の活性化エネルギーで あり，古典的核生成理論によれば次式で与えられる。

$$
\Delta g_{\max }=\frac{16}{3} \pi V^{2} \frac{\sigma^{3}}{\Delta G^{2}}
$$

ここで, $V$ は $\mathrm{MnS}$ のル容積, $\Delta G$ は核生成の駆動力, $\sigma$ は $\mathrm{MnS}\left(\mathrm{L}_{2}\right)$ または $\mathrm{MnS}$ と液相 $\mathrm{L}_{1}$ の界面エネルギーであ る、詳細な熱力学データの導出方法は原著(5)(8)を参照してい ただきたいが， $\Delta G\left(\mathrm{~L}_{1} \rightarrow \mathrm{L}_{2}\right)$ と $\Delta G\left(\mathrm{~L}_{1} \rightarrow \mathrm{MnS}\right)$ は，それぞれ $43.8 \mathrm{~kJ} / \mathrm{mol}$ と $43.1 \mathrm{~kJ} / \mathrm{mol}$ であまり相違ない。従って, 界 面エネルギーが $\Delta g_{\max }$ を支配する主因子であると考えられる. $\mathrm{Fe}\left(\mathrm{L}_{1}\right) / \mathrm{MnS}\left(\mathrm{L}_{2}\right), \mathrm{Fe}\left(\mathrm{L}_{1}\right) / \mathrm{MnS}(\mathrm{s})$ の界面エネルギーを，そ れぞれ $0.114 \mathrm{~N} / \mathrm{m}^{(23)}$ と $0.6 \mathrm{~N} / \mathrm{m}^{(7)}$ として共晶組成における $\Delta g_{\text {max }}$ を計算した結果を図 9 に示す。共晶温度よりも僅か $5{ }^{\circ} \mathrm{C}$ 過冷されただけで，準安定系 $\operatorname{MnS}\left(\mathrm{L}_{2}\right)$ が安定系 $\mathrm{MnS}(\mathrm{s})$ よりも核生成しやすくなることを示唆している.このため, $\mathrm{Fe}-\mathrm{Mn}-\mathrm{S} 3$ 元系では準安定系反応が安定系反応よりも優先 したと考えられる。同様な現象は $\mathrm{Cu}-\mathrm{Cu}_{2} \mathrm{~S}$ 系でも観察され

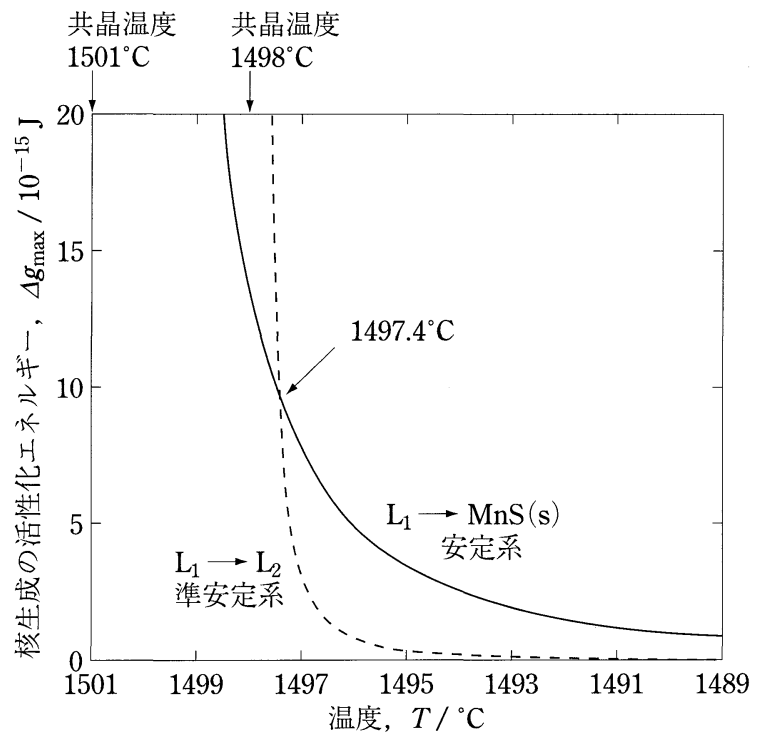

図 $9 \mathrm{Fe}$-rich 液相 $\left(\mathrm{L}_{1}\right)$ から安定系 $\mathrm{MnS}(\mathrm{s})$ および準安 定系 $\mathrm{MnS}\left(\mathrm{L}_{2}\right)$ が核生成するための活性化エネル ギー。

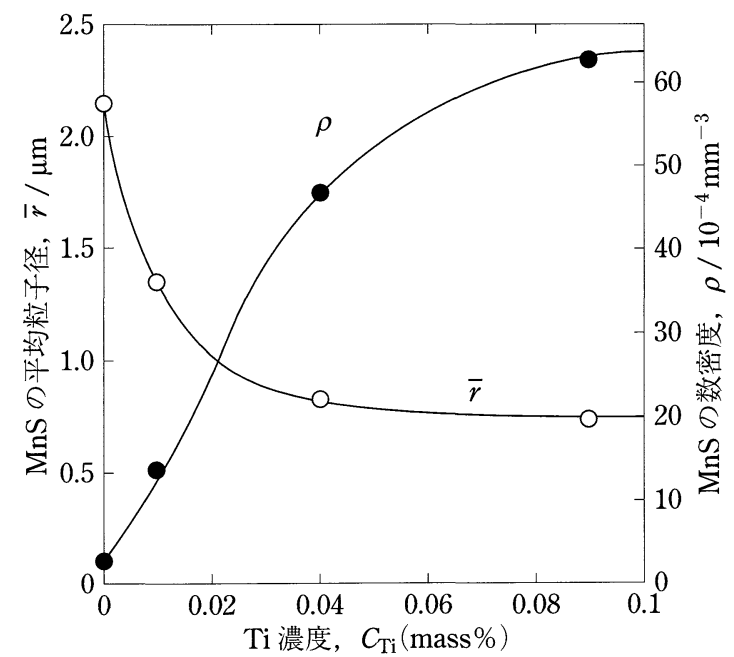

図10 $\mathrm{Fe}-0.1$ mass $\% \mathrm{C}-1$ mass $\% \mathrm{Mn}-0.02$ mass $\% \mathrm{~S}$ 合 金中に生成する偏晶 $\mathrm{MnS}$ の粒径および数密度に 及ぼす Tiの影響。

るので (24)， $\mathrm{M}_{2}$ 型状態図で安定系と準安定系反応の温度差が 小さい場合に共通する現象と考えられる. 添加元素による形 態変化の原因は, 溶湯中に生成する酸化物, 窒化物の核生成 サイトとしての効果, あるいは添加元素により安定系反応と 準安定系反応の温度差が変化することが原因である．詳しい 説明に関しては原著論文を参考にしていただきたい(7) (8).

$\mathrm{Ti}$ の添加は, 形態変化だけでなく分散状態へも大きな影 響を及ぼす。図10は，Ti を微量添加した時の MnSの粒径と 数密度の変化を示している(25). Ti を微量加えると偏晶 $\mathrm{MnS}$ の大きさが著しく小さくなり約 $1 / 3$ になることが明ら かとなった。これは偏晶 $\mathrm{MnS}$ の核生成サイトとなりやすい 


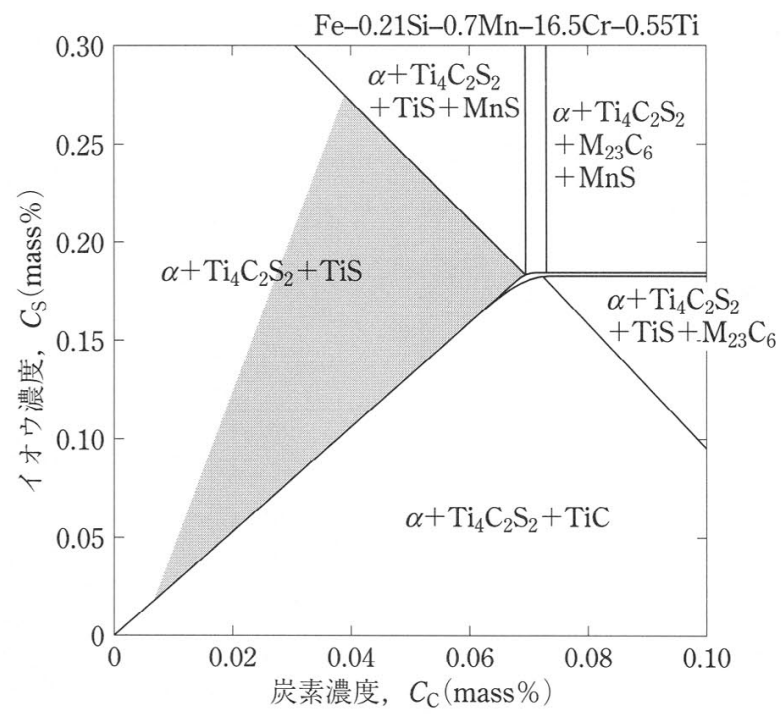

図11 $\mathrm{Fe}-0.21$ mass $\% \mathrm{Si}-0.7$ mass $\% \mathrm{Mn}-16.5$ mass \% $\mathrm{Cr}-0.55$ mass \% Ti-C-S 合金の $800^{\circ} \mathrm{C}$ における計 算状態図。

Ti-Mn 酸化物が微細に分散しやすいためと考えられる。こ のような MnSの微細分散は, フェライト組織の微細化へ有 効に作用するものと期待される.

\section{6. 多元系計算状態図の材料開発への応用}

最近，環境問題等への配慮から $\mathrm{Pb}$ フリー快削鋼の開発が 活発になっている．特に $\mathrm{Pb}$ に代わる被削性改善物質として 硫化物の利用が注目されている。その中で $\mathrm{Ti}_{4} \mathrm{C}_{2} \mathrm{~S}_{2}$ が被削 性改善に有効であることが最近明らかとなってい る(13)(14)(26)。ここでは， $\mathrm{Ti}_{4} \mathrm{C}_{2} \mathrm{~S}_{2}$ を分散した $\mathrm{Pb}$ フリーステ ンレス快削鋼の開発への多元系計算状態図の適用例を述へ る. ステンレス鋼へ $\mathrm{Ti}_{4} \mathrm{C}_{2} \mathrm{~S}_{2}$ を分散させる場合，特に重要と なるのは合金中の $\mathrm{Cr}, \mathrm{Ti}, \mathrm{Mn}, \mathrm{C}, \mathrm{S}$ などの組成バランスであ る.これらの元素は Fe 中で硫化物，炭化物を生成しやすい ため，組成バランスにより， $\mathrm{CrS}, \mathrm{MnS}, \mathrm{TiS}, \mathrm{TiC}, \mathrm{M}_{23} \mathrm{C}_{6}$ な ぞの化合物を生成する可能性がある。この中で $\mathrm{TiC}, \mathrm{M}_{23} \mathrm{C}_{6}$ は非常に硬い化合物であるため被削性へ悪影響を及ぼし，末 た， $\mathrm{MnS}, \mathrm{M}_{23} \mathrm{C}_{6}$ は耐食性の著しい劣化をもたらすことが知 られている。つまり，快削ステンレス鋼へは， $\mathrm{TiC}, \mathrm{MnS}$, $\mathrm{M}_{23} \mathrm{C}_{6}$ の析出は避けなければならない。図11はSUS430を ベースとした合金で C および $\mathrm{S}$ 濃度を変化させた時の $800^{\circ} \mathrm{C}$ における等温断面状態図を示している。 $\mathrm{Ti}_{4} \mathrm{C}_{2} \mathrm{~S}_{2}$ だけが析出 する $\alpha+\mathrm{Ti}_{4} \mathrm{C}_{2} \mathrm{~S}_{2}$ の 2 相領域は非常に狭く，この領域内で組 成コントロールするのは実用的には困難である。従って, $\mathrm{TiC}, \mathrm{MnS}, \mathrm{M}_{23} \mathrm{C}_{6}$ の析出をさけながら $\mathrm{Ti}_{4} \mathrm{C}_{2} \mathrm{~S}_{2}$ を析出させる ためには， $\alpha+\mathrm{Ti}_{4} \mathrm{C}_{2} \mathrm{~S}_{2}+\mathrm{TiS} の 3$ 相領域が現実的であり，特 に $\mathrm{Ti}_{4} \mathrm{C}_{2} \mathrm{~S}_{2}$ の分量が多く析出するグレーの組成領域内から開 発鋼の組成を絞り込めばよいことが計算から示唆される。ち なみに $\mathrm{Ti}_{4} \mathrm{C}_{2} \mathrm{~S}_{2}$ は凝固時には棒状共晶硫化物の形態で生成す るが，熱間加工時に分断され微細に分散する(13)。このよう
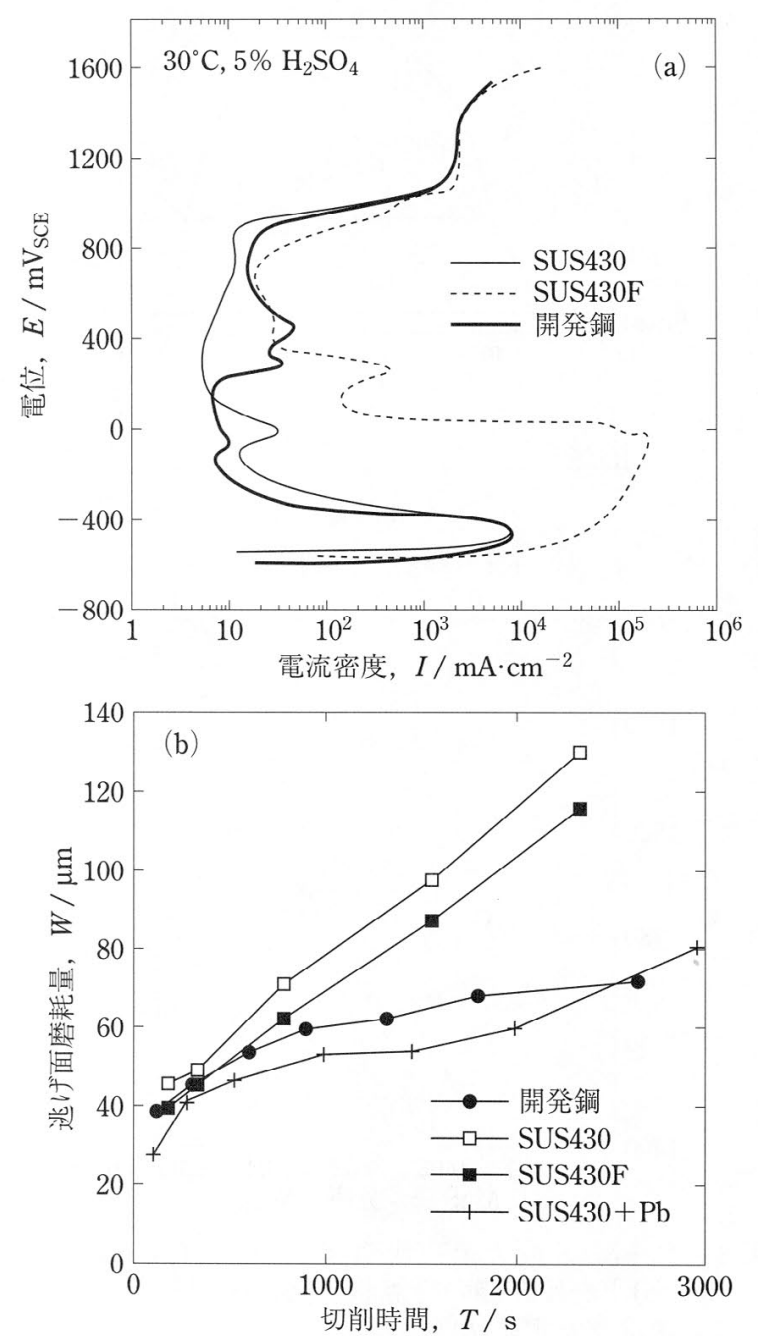

図12 $\mathrm{Ti}_{4} \mathrm{C}_{2} \mathrm{~S}_{2}$ を分散させたフェライト系快削ステンレ 又鋼の (a) 分極曲線と (b) 旋削試験にお计万工具 の逃げ面磨耗量.

な合金設計指針で開発された合金の特性を図 12 に示し た ${ }^{(13)}$ 。図12（a）開発鋼の分極曲線を示している。 SUS430F は MnS を分散させたイオウ快削ステンレス鋼で あるが, 臨界不動態化電流密度も大きく SUS430 々比較す ると非常に耐食性に劣ることがわかる。これは，MnSを分 散させた快削ステンレス鋼の欠点であるが，開発鋼は硫化物 を分散させたのにも拘わらず，分極曲線はイオウを含まない ベース鋼 SUS430 と同様であり，耐食性がよいことがわか る. また, 図12(b) は切削試験時の工具の逃げ面磨耗量を測 定した結果であるが，開発鋼は SUS430 S SUS430F と比較 して工具磨耗量も少なく，被削性に優れていることがわか る.これと同様に多元系計算状態図を利用して電磁ステンレ 又鋼(27)，インバー合金，耐食鋼， Ti 合金， $\mathrm{Cu}$ 合金 ${ }^{(28)}$ の快 削化も行われている.

\section{7. を め}

鉄鋼材料中に生成する硫化物の相平衡と組織制御に関して 
概説した. 硫化物相を含む多元系状態図の解析は現在も継続 して抢り, 今後, より多くの硫化物に関して定量的な議論が 可能になる.

鉄鋼材料中への硫化物分散の効用は，硫化物自体の物性も 明らかでない部分が多いため, また未探索の領域が多く, $\mathrm{Ti}_{4} \mathrm{C}_{2} \mathrm{~S}_{2}$ を分散した $\mathrm{Pb}$ フリー快削ステンレス鋼のような新 しい合金開発の宝庫になることが期待できる。オキサイド． メタラジーとともにサルファイド・メタラジーの研究が重要 であると考えられ，そのためにも，各種硫化物の基礎データ の蓄積が求められる.

本稿は，著者らのグループが行ってきた金属材料中の硫化 物に関する研究成果の一部である、その研究を遂行するにあ たり，御指導を頂いた東北大学名誉教授 西沢泰二先生に感 謝申し上げるとともに, 研究に御協力頂いた九州工業大学助 教授 大谷博司先生, 卒論, 修論として協力頂いた学生諸氏 に深謝致します。また，快削鋼の開発の共同研究にご尽力い ただいた，大同特殊鋼株式会社 岡部道生氏，野田俊治氏， 清水哲也氏, 石川浩一氏, 東北特殊鋼株式会社 滝口常美 氏，汇幡貴司氏へ感謝いたします。

\section{文献}

(1) J. Takamura and S. Mizoguchi: Proc. $6^{\text {th }}$ Int. Iron and Steel Cong., 1(1990), 591.

(2) M. Morinaga, Y. Murata, R. Hashizume and Y. Sawaragi: ISIJ Int., 41(2001), 314.

（3）金子秀夫, 西沢泰二, 玉置維昭：日本金属学会誌，27(1963), 299.

(4) K. Oikawa, H. Mitsui, H. Ohtani and K. Ishida: ISIJ Int., 40(2000), 182.

(5) H. Ohtani, K. Oikawa and K. Ishida: High Temp. Mater. Processing, 19(2000), 197.

(6) K. Oikawa, H. Mitsui, T. Ebata, T. Shimizu and K. Ishida: Proc. $4^{\text {th }}$ Stainless Steel Science and Market Cong., 2(2002), 40.

（7）及川勝成, 大谷博司, 石田清仁, 西沢泰二：鉄と鋼, 80(1994), 623 .

(8) K. Oikawa, H. Ohtani, K. Ishida and T. Nishizawa: ISIJ Int., 35(1995), 402.

(9) Y. Ohuchi, K. Oikawa, I. Ohnuma and K. Ishida: Mater. Sci. Forum, 284-286 (1998), 509.

(10) K. Oikawa, Sh. Sumi and K. Ishida: Z. Metallkd., 90(1999), 13.

(11) K. Oikawa, S.-I. Sumi and K. Ishida: J. Phase Equilibria, 20 (1999), 215

(12) H. Mitsui, K. Oikawa, I. Ohnuma, R. Kainuma and K. Ishida: ISIJ Int., 42 (2002), 1297.

(13) K. Oikawa, H. Mitsui, T. Ebata, T. Takiguchi, T. Shimizu, K. Ishikawa, T. Noda, M. Okabe and K. Ishida: ISIJ Int., 42(2002), 806.

（14）清水哲也, 石川浩一, 野出俊治, 及川勝成, 石田清仁: 電気 製鋼， 73 (2002)，121.

（15）西沢泰二：日本金属学会セミナ一「材料開発・設計に打沙る 状態図の基礎と応用」，日本金属学会，(1995), 27.

(16) T. B. Massalski: Binary Alloy Phase Diagrams, Materials Park, OH, ASM International, (1990).

（17）金子秀夫，西沢泰二，玉置維昭：日本金属学会誌，27(1963), 312.

(18) 光井 啓：東北大学博士学位論文, (2004).

(19) H. Ohtani and M. Hillert: CALPHAD, 15 (1991), 41.

(20) H. Ohtani, T. Tanaka, M. Hasebe and T. Nishizawa: CALPHAD, 12 (1988), 41.

(21) C. E. Sims and F. B. Dahle: Trans. Amer. Foundarymen's ASS., 46(1938), 65.

(22) H. Fredriksson and M. Hillert: J. Iron and Steel Inst., 209 (1971), 109.

(23) 孫海平, 伊藤礼輔, 中島邦彦, 森克彦: 鉄と鋼, 81(1995), 888 .

（24）及川勝成, 川下宜郎, 大谷博司, 石田清仁, 西沢泰二：日本 金属学会誌，59(1995)，1207.

(25) K. Oikawa, K. Ishida and T. Nishizawa: ISIJ Int., 37(1997), 332.

（26）渡里宏二，垣見治則，松本 斉：おてりあ， $4 \mathbf{1}(2002), 57$.

(27) T. Ebata, T. Shimizu, K. Oikawa, H. Mitsui and K. Ishida: Proc. $4^{\text {th }}$ Stainless Steel Science and Market Congress, $2(2002), 81$.

(28) K. Oikawa, H. Ido, H. Mitsui and K. Ishida: Mater. Trans., 44 (2003), 2088

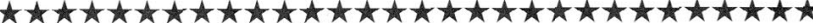 及川勝成 \\ 1996年 束北大学大学院工学研究科博士課程修了 \\ 同年 通商産業省工業技術東北工業技術研究所入所 \\ 2001年 独立行政法人産業技術総合研究所入改組, 現在に至る \\ 専門分野：材料組織学 \\ 鉄鋼朴料，磁性材料の状能㘠および組織制御に関する研究を中心に活動中。}

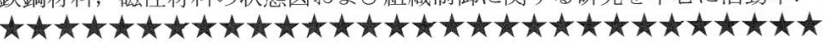

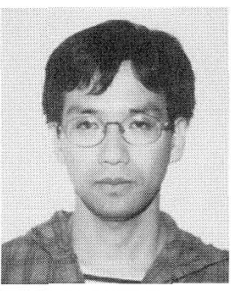

及川勝成

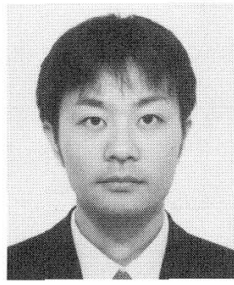

光井啓

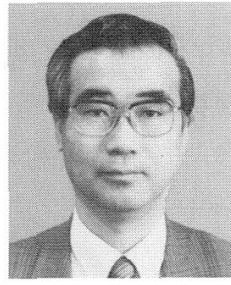

石田清仁 